\title{
Localization of Adenylyl and Guanylyl Cyclase in Rat Brain by in situ Hybridization: Comparison with Calmodulin mRNA Distribution
}

\author{
Isao Matsuoka, Galicia Giuili, Madeleine Poyard, Dominique Stengel, Jasmine Parma, Georges Guellaen, and \\ Jacques Hanoune
}

Institut National de la Santé et de la Recherche Médicale, U-99, Hôpital Henri Mondor, F-94010 Créteil, France

Cyclic nucleotides are major intracellular mediators in the signal transduction events in synaptic neurotransmission of the CNS. Intracellular $\mathrm{Ca}^{2+}$ is known to regulate adenylyl cyclase $(\mathrm{AC})$ in a calmodulin (CaM)-dependent manner, and guanylyl cyclase (GC), in an indirect manner through CaMsensitive nitric oxide synthase. To ascertain the physiological significance of cyclic nucleotide second messenger systems, we have localized the mRNAs encoding AC, GC, and $\mathrm{CaM}$ in the rat brain by in situ hybridization using ${ }^{35} \mathrm{~S}-$ labeled RNA probes. The AC mRNA is widely distributed throughout the brain; strong hybridization signal was observed in the granular layers of the cerebellum, in the pyramidal and granule cells of the hippocampus, and in the olfactory system. These AC mRNA localizations are compatible with the distribution of $\mathrm{Ca}^{2}+/ \mathrm{CaM}-$ sensitive $\mathrm{AC}$ activities. In contrast to AC mRNA distribution, GC mRNA has a more limited distribution. Significant signals were observed in the striatum, in the pyramidal and granule cells of the hippocampus, in the olfactory system, in the inferior and superior colliculus, in the Purkinje cells of the cerebellum, in the locus coeruleus, and in many pyramidal cells in the layers II-III and $V$ of the cerebral cortex, and mainly, in the occipital cortex. In some discrete brain regions, a close correlation was found between enzyme activity and mRNA hybridization signal of GC. The distinct distribution of AC and GC mRNAs suggests that different cyclic nucleotide second messenger systems have specialized functions. On the other hand, CaM mRNA was colocalized with the AC and GC mRNA, but its distribution was more abundant and specific for neuronal cells, since there was little hybridization signal with CaM probe in neuronal fiber regions such as the corpus callosum and the anterior commissure. The high expression of CaM mRNA in neuronal cells is in agreement with its biochemical role in the regulation of various enzymes. Results of the present study should help in analyzing the role of cyclic nucleotides and $\mathrm{CaM}$ in physiological and pathological situations in the CNS.

\footnotetext{
Received Jan. 24, 1992; revised Mar. 19, 1992; accepted Mar. 24, 1992.

We thank Dr. Robert Barouki and Dr. Marc Peschanski for helpful discussion and comments on the manuscript, Dr. Françoise Pecker and Dr. Brigitte Onteniente for valuable advice, Dr. Anthony R. Means (Texas) for the generous gift of calmodulin cDNA, and Dr. Masaki Nakane (Tokyo) for the generous gift of soluble guanylyl cyclase cDNA. We are also grateful to Edith Grandvilliers, Lydie Rosario, and Corinne Dutreuil for expert secretarial assistance. This work was supported by the Institut National de la Santé et de la Recherche Médicale, the Université Paris-Val de Marne, and the Fondation de France.

Correspondence should be sent to Dr. Jacques Hanoune at the above address. Copyright (C) 1992 Society for Neuroscience $0270-6474 / 92 / 123350-11 \$ 05.00 / 0$
}

Both cyclic nucleotides, cAMP and cGMP, are recognized as intracellular messenger molecules mediating the effects of extracellular signals in mammalian tissues. In the CNS, a number of neurotransmitters have been shown to affect the intracellular cyclic nucleotide levels by modulating adenylyl (AC) and guanylyl (GC) cyclase activities (Kebabian, 1977). The pivotal roles of the cyclic nucleotide second messenger systems in the neuronal functions and in the synaptic transmissions are also supported by the finding of high AC and GC activities in the brain (Sutherland et al., 1962; Murad et al., 1978).

$\mathrm{AC}$ is generally recognized as a membrane-associated enzyme. It has been well established that the regulation of AC activity by hormone- and/or neurotransmitter-stimulated receptor is mediated by either stimulatory or inhibitory heterotrimeric GTPbinding proteins (G-proteins; see review by Gilman, 1987). $\mathrm{Ca}^{2+/}$ calmodulin (CaM) also appears to stimulate $\mathrm{AC}$ directly in the brain (Brostrom et al., 1975; Cheung et al., 1975) as well as in some peripheral tissues (Valverde et al., 1979; Piascik et al., 1983; Panchenko and Tkachuk, 1984). Biochemical and immunological studies have revealed that, although $\mathrm{Ca}^{2+} / \mathrm{CaM}-$ insensitive enzyme is present in the brain, the major form of $\mathrm{AC}$ in this organ is $\mathrm{Ca}^{2+} / \mathrm{CaM}$ sensitive (Rosenberg and Storm, 1987; Mollner and Pfeuffer, 1988). Recently, molecular cloning has provided evidence for the existence of multiple forms of membrane-associated AC in mammalian tissues. Those are $\mathrm{Ca}^{2+}$ CaM-sensitive AC (type I; Krupinski et al., 1989), olfactoryspecific AC (type III; Bakalyar and Reed, 1990), and $\mathrm{Ca}^{2}+/ \mathrm{CaM}-$ insensitive, G-protein-regulated ACs (type II, Feinstein et al., 1991; and type IV, Gao and Gilman, 1991). Recently, we also cloned and sequenced two different forms of ACs from a human brain cDNA library (Parma et al., 1991; Stengel et al., in press). These findings indicate that many types of ACs are involved in neuronal functions in brain, although the physiological significance of each $\mathrm{AC}$ remains to be elucidated.

On the other hand, in most tissues, GC is present in both soluble and membrane-bound forms. In the CNS, the soluble form of $\mathrm{GC}$ is responsible for various neurotransmitter-induced cGMP elevations, whereas different forms of membrane-bound enzymes are identified as the receptors for the natriuretic peptides (Schulz et al., 1991). Because of the cytosolic localization of the soluble $\mathrm{GC}$, it has been postulated that a signal transduction mechanism is involved in the coupling of neurotransmitter receptor stimulation with cellular cGMP response (Goldberg et al., 1978). It is now believed that nitric oxide (NO) would play this role and would activate soluble GC by transferring an electron to a heme group that is associated with the enzyme. Garthwaite et al. (1988) have demonstrated that stimulation of primary cultured neuronal cells with NMDA, a glutamate re- 
ceptor agonist, caused a release of NO. This $\mathrm{NO}$ is produced from arginine by NO synthase, which has been shown to require CaM for its activity (Bredt and Snyder, 1990). Stimulation of many neurotransmitter receptors that are not directly coupled to $\mathrm{AC}$ or $\mathrm{GC}$ systems produces $\mathrm{Ca}^{2+}$ mobilization through voltage-dependent $\mathrm{Ca}^{2+}$ channels (Augustine et al., 1987) or phosphoinositide hydrolysis by phospholipase C (Berridge, 1988). Thus, in the brain, multiplc signal transduction systems seem to be operative through $\mathrm{Ca}^{2+}$-dependent mechanisms that might involve CaM.

Although a large amount of information has been accumulated on the causal relationships between the functions of several neurotransmitters and the cyclic nucleotide second messenger systems (Kebabian, 1977), the anatomical and physiological complexity of the brain makes it difficult to define the roles of cyclic nucleotides in specific regions of this organ. To understand the significance of these second messengers in specific neuronal systems, it is important to localize the enzyme involved in each signaling mechanism in the CNS. Recently, several enzymes and neurotransmitter receptors have been mapped in the brain by in situ hybridization (see a review by Harrison and Pearson, 1990). The localization of a particular mRNA species in tissue sections indicates the sites of the synthesis of the coding protein at the cellular level. Furthermore, the relative abundance of mRNA in different regions may provide an index of the relative levels of the corresponding protein. In the present investigation, we used cDNA of GC (Nakane et al., 1988, 1990) and CaM (Putkey et al., 1983) as well as that of AC, isolated in our laboratory (Parma et al., 1991), for probe preparations, to identify the localization of $\mathrm{AC}$ and GC mRNA in the rat brain by in situ hybridization, and to compare their distribution with that of CaM mRNA.

\section{Materials and Methods}

Female Wistar rats (150-200 gm) were decapitated, and the brains were rapidly isolated, frozen in dry-ice isopentane at $-20^{\circ} \mathrm{C}$, and stored at $-80^{\circ} \mathrm{C}$ until use. Sections $(10-15 \mu \mathrm{m})$ were cut in a cryostat, thaw mounted on gelatin-coatcd microscopc slides, and stored at $-20^{\circ} \mathrm{C}$

Probes. In a preliminary experiment, we tested double-stranded cDNA as well as single-stranded antisense RNA for in situ hybridization histochemistry. Although the specific signal and its localization are similar using both types of probe, posthybridization treatment with RNase $A$ and $T$, markedly reduced the background of the RNA probe as compared to that of the cDNA probe. In addition, nonspecific binding of antisense RNA probe could be evaluated by using a sense RNA probe. Experiments described here were therefore performed with RNA probes.

A 2.2 kilobase (kb) human brain AC cDNA, corresponding to the $3^{\prime}$ portion of the coding region, was isolated from a $\lambda \mathrm{gt} 10$ library and subcloned into pGEM3-Zf(+) vector as described previously (Parma et al., 1991). Prior to in vitro transcription, this plasmid was linearized with either SacI or BglII for antisense or sense probe, respectively. A chicken brain CaM cDNA (297 base IIindIII/PstI fragment; Putkcy ct al., 1983) subcloned into the pGEMI was kindly provided by Dr. Anthony R. Means (Department of Cell Biology, Baylor College of Medicine, Houston, IX). This plasmid was linearized with either EcoRI or PstI for antisense or sense probe, respectively. The in vitro transcription was carried out at $37^{\circ} \mathrm{C}$ for $60 \mathrm{~min}$ in a $20 \mu \mathrm{l}$ reaction mixture containing $1 \mu \mathrm{g}$ of linearized plasmid templates, and T7 or SP6 RNA polymerase in the presence of ${ }^{35} \mathrm{~S}$-labeled UTP $(>1000 \mathrm{Ci} / \mathrm{mmol}, 1 \mathrm{Ci}=37 \mathrm{GBq}$; Amersham). A pBluescript with an insert of $2.6 \mathrm{~kb} \mathrm{cDNA}$, containing the entire coding region for the $70 \mathrm{kDa}$ rat lung soluble $\mathrm{GC}$ subunit (Nakane et al., 1988), was kindly provided by Dr. Masaki Nakane (Tokyo Metropolitan Institute for Neurosciences). The plasmid linearized in the middle of it by StuI was used as the template for in vitro transcription with $\mathrm{T} 3$ or $\mathrm{T} 7 \mathrm{RNA}$ polymerase in the presence of ${ }^{35} \mathrm{~S}$ labeled UTP. The ${ }^{35} \mathrm{~S}$-labeled probes were separated from free nuclcotides by spin column (Sephadex G-50 fine) and then concentrated by ethanol precipitation.
In situ hybridization. The sections fixed in $4 \%(\mathrm{w} / \mathrm{v})$ paraformaldehyde were acetylated in $0.25 \%$ acetic anhydride in $0.1 \mathrm{M}$ triethanolamine (pH 8 ) solution. The sections were then rinsed in $2 \times$ saline-sodium citrate (SSC); dehydrated and defatted by an ethanol/chloroform series: $70 \%$ (5 min), 90\% (5 min), and 100\% ethanol (5 min), chloroform ( $10 \mathrm{~min})$, $100 \%$ ethanol ( $5 \mathrm{~min})$; and air dried. Before hybridization, each section was prchybridized with $50 \mu \mathrm{l}$ of hybridization buffer in the absence of probe under Parafilm coverslips in a humid chamber at $42^{\circ} \mathrm{C}$ for $6-12$ $\mathrm{hr}$. The prolonged prehybridization significantly reduced the background without affecting the specific signal intensity. The hybridization buffer had the following composition: $50 \%$ deionized formamide, 0.1 M sodium phosphate $(\mathrm{pH} 7.0), 4 \times \mathrm{SSC}, 1 \times$ Denhardt's solution $(0.02 \%$ Ficoll, $0.02 \%$ polyvinylpyrrolidone, $0.02 \%$ bovine serum albumin), 0.1 $\mathrm{M}$ dithiothreitol, $1 \%$ sodium laurylsarkosine, and $250 \mu \mathrm{g} / \mathrm{ml}$ denatured salmon sperm DNA. The sections were then briefly rinsed in $2 \times \mathrm{SSC}$, dehydrated by ethanol, and air dried. In situ hybridization was performed in $30-50 \mu$ l of the hybridization buffer containing $10 \%$ dextran sulfate and ${ }^{35} S$-labeled antisense RNA probes $\left(1.0 \times 10^{7} \mathrm{cpm} / \mathrm{ml}\right)$ under Parafilm coverslips in a humid chamber at $42^{\circ} \mathrm{C}$ for $16-24 \mathrm{hr}$. After the hybridization, sections were rinsed in $1 \times$ SSC for $30 \mathrm{~min}$ at room temperature. In order to remove nonspecifically bound single-stranded probe, the sections were treated with a solution containing $20 \mu \mathrm{g} / \mathrm{ml}$ RNase A, $100 \mathrm{U} / \mathrm{ml}$ RNase $\mathrm{T}_{1}, 0.5 \mathrm{~m} \mathrm{NaCl}, 10 \mathrm{~mm}$ Tris/ $\mathrm{HCl}(\mathrm{pH} 8)$, and $1 \mathrm{~mm}$ EDTA for $30 \mathrm{~min}$ at $37^{\circ} \mathrm{C}$. The sections were further washed in $1 \times \operatorname{SSC}\left(42^{\circ} \mathrm{C}, 30 \mathrm{~min}\right)$ and in $0.1 \times \mathrm{SSC}\left(42^{\circ} \mathrm{C}, 30 \mathrm{~min} ; 60^{\circ} \mathrm{C}, 30\right.$ min twice). The sections were dried by dehydrating with ethanol, and were exposed to $\mathrm{x}$-ray film (Hyperfilm $\beta$ max, Amersham) for 3-10 d. The sections were then coated with Ilford-K5 emulsion and exposed for $2-4$ weeks at $4^{\circ} \mathrm{C}$. The slides were developed, fixed, and stained through the emulsion with cresyl violet. Nonspecific hybridizations were determined by parallel incubation of adjacent sections with ${ }^{35} \mathrm{~S}$-labeled sense RNA probe. Furthermore, in some experiments, prehybridization was performed in the presence of an excess amount of unlabeled antisense probes (about 50-fold).

Northern blot analysis. Northern blot analysis was performed using the same probes as for the in situ hybridization analysis but labeled with $\alpha{ }^{32} \mathrm{P}-\mathrm{UTP}$. PolyA ${ }^{+}$RNA was isolated from whole rat brain. Denatured polyA ${ }^{+}$RNA $(4 \mu \mathrm{g})$ was fractionated on $1 \%$ agarose, $2.2 \mathrm{M}$ formaldehyde gels and transferred onto a Hybond $\mathrm{N}^{+}$membrane (Amersham). The membranes were prehybridized overnight at $42^{\circ} \mathrm{C}$ in a buffer containing $50 \%$ formamide, $4 \times \mathrm{SSC}, 50 \mathrm{~mm}$ sodium phosphate $(\mathrm{pH} \mathrm{7),} 5 \times$ Denhardt's solution, $1 \% \mathrm{SDS}$, and $250 \mu \mathrm{g} / \mathrm{ml}$ denatured salmon sperm DNA. Hybridization was carried out at $42^{\circ} \mathrm{C}$. for $24 \mathrm{hr}$ in the same buffer containing $10 \%$ dextran sulfate and $1.0 \times 10^{6} \mathrm{cpm} / \mathrm{ml}$ of ${ }^{32} \mathrm{P}$-labeled probes. Membranes were then washed for $1 \mathrm{hr}$ in three changes of $1 \times$ SSC, $0.5 \%$ SDS at $42^{\circ} \mathrm{C}$, and finally in $0.1 \times \mathrm{SSC}, 0.5 \%$ SDS at $70^{\circ} \mathrm{C}$ for $30 \mathrm{~min}$, and examined by autoradiography.

$A C$ and $G C$ assay. The rat brains were isolated as described above, and selective brain regions such as the cerebral cortex, the cerebellum, the olfactory bulb, the hippocampus, the striatum, and the pons, were immediately dissected. The tissues were placed in $10 \mathrm{vol}$ of an ice-cold buffer containing $10 \mathrm{~mm}$ Tris/ $\mathrm{HCl}(\mathrm{pH} 7.4), 5 \mathrm{~mm}$ dithiothreitol, and $0.1 \mathrm{~mm}$ EGTA, and homogenized using Dounce homogenizer. The homogenate was centrifuged at $150 \times g$ for $5 \mathrm{~min}$ at $4^{\circ} \mathrm{C}$, and the pellet was discarded. Subsequently, the supernatant was centrifuged at 12,000 $\times g$ for $30 \mathrm{~min}$ at $4^{\circ} \mathrm{C}$. The supernatant was further centrifuged at $105,000 \times g$ for $1 \mathrm{hr}$ at $4^{\circ} \mathrm{C}$, and the last supernatant fraction, containing soluble GC, was stored at $-80^{\circ} \mathrm{C}$ until use. The pellets obtained by centrifugation at $12,000 \times g$ were resuspended in a washing buffer containing $50 \mathrm{~mm}$ Tris/ $\mathrm{HCl}$ (pH 7.4), $1 \mathrm{~mm}$ dithiothreitol, $1 \mathrm{~mm}$ EDTA, $0.1 \mathrm{mg} / \mathrm{ml}$ phenylmethylsulfonyl fluoride, and $0.1 \mathrm{mg} / \mathrm{ml}$ benzamidin, and were centrifuged again at $12,000 \times g$ for $10 \mathrm{~min}$ at $4^{\circ} \mathrm{C}$. This washing process was repeated three times in order to remove endogenous $\mathrm{Ca}^{2+}$ and $\mathrm{CaM}$. The final pellet, corresponding to the membrane fraction containing $\mathrm{AC}$, was resuspended in the same buffer and stored at $-80^{\circ} \mathrm{C}$ until use.

Prior to the $\mathrm{AC}$ assay, frozen membranes were thawed and diluted fivefold with a buffer containing $50 \mathrm{~mm}$ Tris/ $\mathrm{HCl}(\mathrm{pH} \mathrm{7.4})$ and $2 \mathrm{~mm}$ EGTA. After centrifugation at $12,000 \times g$ for $10 \mathrm{~min}$ at $4^{\circ} \mathrm{C}$, the pellet was resuspended in the above buffer to give a final EGTA concentration of $1 \mathrm{~mm}$ in AC assay. AC activity was measured as described previously (Stengel and Hanoune, 1981) with minor modification. The standard reaction mixture contained $50 \mathrm{~mm}$ Tris/ $\mathrm{HCl}(\mathrm{pH} \mathrm{7.4),} 1 \mathrm{~mm}$ EGTA, 5 $\mathrm{mm} \mathrm{MgCl}, 1 \mathrm{~mm}$ ATP containing $\alpha^{-72}$ P-ATP $\left(1 \times 10^{6} \mathrm{cpm}\right), 1 \mathrm{~mm}$ cyclic AMP containing $8-{ }^{3} \mathrm{H}$-cyclic AMP $(10,000 \mathrm{cpm}), 50 \mu \mathrm{M}$ GTP, $0.2 \mathrm{~mm} 3$-isobutyl-1-methylxanthine, $25 \mathrm{~mm}$ phosphocreatine, $1 \mathrm{mg}$ / 


\begin{tabular}{|c|c|c|c|c|c|}
\hline \multirow[b]{3}{*}{$\underline{\text { Tissues }}$} & \multicolumn{3}{|c|}{$\begin{array}{l}\text { AC activity } \\
(\mathrm{nmol} / \mathrm{mg} \text { protein } / \mathrm{min})\end{array}$} & \multirow{2}{*}{\multicolumn{2}{|c|}{$\begin{array}{l}\text { GC activity } \\
\text { (pmol/mg } \\
\text { protein } / \mathrm{min} \text { ) }\end{array}$}} \\
\hline & \multirow[b]{2}{*}{ Basal } & \multirow{2}{*}{$\begin{array}{l}\text { For- } \\
\text { skolin }\end{array}$} & \multirow{2}{*}{$\begin{array}{l}\mathrm{Ca}^{2+1} \\
\mathrm{CaM}\end{array}$} & & \\
\hline & & & & Basal & NP \\
\hline Cerebral cortex & 0.26 & 3.14 & 0.98 & 16.6 & 215 \\
\hline Cerebellum & 0.32 & 3.06 & 1.49 & 21.7 & 139 \\
\hline Olfactory bulb & 0.28 & 2.89 & 0.64 & 18.4 & 97.3 \\
\hline Hippocampus & 0.23 & 2.53 & 0.81 & 20.1 & 249 \\
\hline Striatum & 0.22 & 5.17 & 0.57 & 57.5 & 735 \\
\hline Pons & 0.24 & 1.73 & 0.61 & ND & ND \\
\hline
\end{tabular}

Values represent means of triplicate experiments $\pm 5 \%$. ND, not determined. ${ }^{a} \mathrm{AC}$ activity was measured in the absence (Basal), or presence of $10 \mu \mathrm{M}$ forskolin, or $1 \mu \mathrm{M}$ calmodulin $+10 \mu \mathrm{M}$ free calcium.

${ }^{\circ} \mathrm{GC}$ activity was measured in the absence (Basal), or presence of $1 \mathrm{~mm}$ nitroprusside (NP).

$\mathrm{ml}$ creatine phosphokinase, and $30 \mu \mathrm{g}$ of membrane protein in a final volume of $60 \mu \mathrm{l}$. Reactions were initiated by addition of membranes and conducted for $10 \mathrm{~min}$ at $37^{\circ} \mathrm{C}$. The reactions were terminated by addition of $200 \mu \mathrm{l}$ of $0.1 \mathrm{M} \mathrm{HCl}$, followed by boiling for $7 \mathrm{~min}$. Cylic AMP formed during the incubation was separated by Alumina column and corrected for recovery of ${ }^{3} \mathrm{H}$-cyclic AMP.

GC activity was measured as described previously (Haguenauer-Tsapis et al., 1981) with minor modifications. GC assay was performed in a reaction mixture containing $50 \mathrm{~mm}$ Tris $/ \mathrm{HCl}(\mathrm{pH} 7.6), 0.1$ mM EGTA, $4 \mathrm{~mm} \mathrm{MgCl}, 1 \mathrm{~mm}$ GTP containing $\alpha{ }^{32}$ P-GTP $\left(2 \times 10^{6} \mathrm{cpm}\right), 1 \mathrm{~mm}$ cyclic GMP containing $8{ }^{-3} \mathrm{H}$-cyclic GMP $(20,000-30,000 \mathrm{cpm}), 1.25$ mM 3-isobutyl-1-methylxanthine, $7.5 \mathrm{~mm}$ phosphocreatine, $1 \mathrm{mg} / \mathrm{ml}$ creatine phosphokinase, and $60 \mu \mathrm{g}$ protein of the soluble fraction in a final volume of $80 \mu \mathrm{l}$. Prior to incubation, the reaction mixtures containing the enzyme fractions but not the substrate (GTP, cyclic GMP, and $\mathrm{MgCl}_{2}$ ) were preincubated with or without nitroprusside at $4^{\circ} \mathrm{C}$ for $10 \mathrm{~min}$. The reactions were then initiated by adding the substrate to the reaction mixtures, and incubations were performed at $37^{\circ} \mathrm{C}$ for 10 $\min$. The reactions were terminated by adding $200 \mu \mathrm{l}$ of $0.1 \mathrm{~N} \mathrm{HCl}$ and then boiling for $7 \mathrm{~min}$. The cyclic GMP formed was determined as in the AC assay. Recovery was monitored with ${ }^{3} \mathrm{H}$-cyclic GMP.

\section{Results}

\section{$A C$ and $G C$ activities in various brain regions}

We first examined AC and GC activities in various regions of the rat brain, such as the cerebral cortex, cerebellum, olfactory bulb, hippocampus, striatum, and pons. Table 1 summarizes the results obtained from those experiments. The basal $\mathrm{AC}$ activities in the brain regions were similar. Forskolin $(10 \mu \mathrm{M})$ and $\mathrm{Ca}^{2+} / \mathrm{CaM}$ markedly stimulated the AC activities of all brain regions examined, although the extent of stimulation varied from one area to the other. The forskolin stimulation of $\mathrm{AC}$ activity was the most pronounced in the striatum (23-fold above basal value) and the weakest in the pons (about 6-fold). In other regions, forskolin increased AC activity about 10 -fold. In contrast, the effect of $\mathrm{Ca}^{2+} / \mathrm{CaM}$ was relatively small in the striatum (2.7-fold above basal value) as compared to the cerebellum (4.7fold), the cerebral cortex (3.8-fold), or the hippocampus (3.6fold).

The basal activities of GC were also similar in those regions except for the striatum. The enzyme from the striatum showed a 2.5-3 times higher basal activity than that from other regions. Nitroprusside (1 mM) markedly increased the GC activities of all brain regions tested. The effect of nitroprusside on GC activities was more significant in the striatum (13-fold), in the cerebral cortex (13-fold), and in the hippocampus (12-fold) than in the cerebellum (6.4-fold) and in the olfactory bulb (5.3-fold).

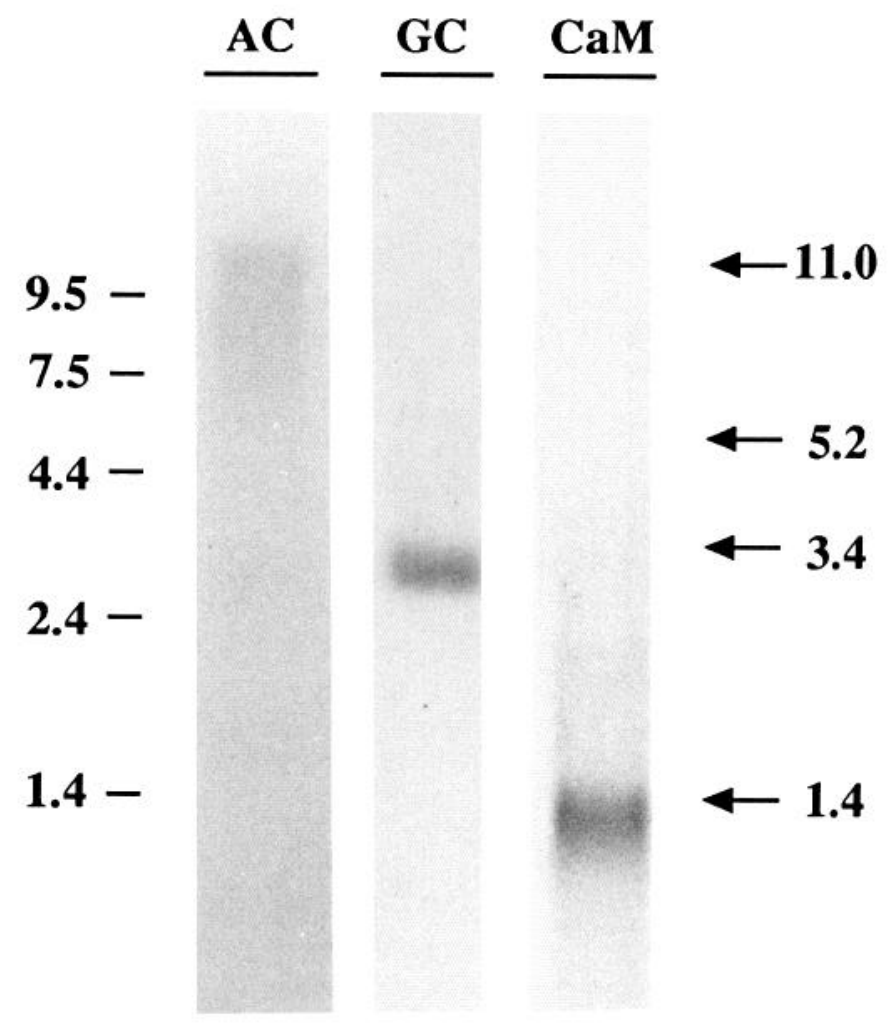

Figure 1. Northern blot analysis of rat brain AC, GC, and CaM mRNAs. $\mathrm{PolyA}^{+}$from whole rat brain was denatured; subjected to electrophoresis in a 1\% agarose, $2.2 \mathrm{~m}$ formaldehyde gel; transferred to nylon membrane; and hybridized with the probe for AC, GC, or CaM. Four micrograms of RNA were added per lane. RNA sizes are given in kilobases.

The present data are in good agreement with previous data from the literature (Hofmann et al., 1977; Bockaert, 1981; Cooper et al., 1988).

\section{Northern blot analysis}

In order to ascertain the specificity of the probes used for in situ hybridization analysis, polyA ${ }^{+}$RNA from the whole rat brain was probed with ${ }^{32} \mathrm{P}$-labeled antisense RNA of AC, GC, and $\mathrm{CaM}$ (Fig. 1). In the polyA+ RNA blots, the AC probe hybridized constantly to RNAs of about $11 \mathrm{~kb}$ in size and, inconstantly, to RNAs of about 5 and $2.5 \mathrm{~kb}$. The larger RNA species is similar to the mRNA of bovine brain CaM-sensitive AC reported by Krupinski et al. (1989), whereas another two smaller RNAs appear to have different size than mRNAs of rat ACs so far reported (Bakalyar and Reed, 1990; Feinstein et al., 1991; Gao and Gilman, 1991). It is unclear, at present, whether the smaller RNAs are the result of differential processing of a primary RNA transcript, or of degradation during manipulation. Recently, we showed that the same probe hybridized to two RNAs, 10.5 and $5.2 \mathrm{~kb}$ in size, using human brain mRNA (Parma et al., 1991). The GC and CaM probes identified single RNA species of $3.4 \mathrm{~kb}$ and $1.4 \mathrm{~kb}$, respectively. These results are consistent with previous studies for GC by Nakane et al. (1988) and for CaM by SenGupta et al. (1987).

\section{In situ hybridization analysis for $A C, G C$, and CaM $m R N A$}

For in situ hybridization studies, several control experiments were performed to assess nonspecific hybridization. For measurement of nonspecific hybridization, adjacent brain sections 
ADENYLYL CYCLASE Antisense

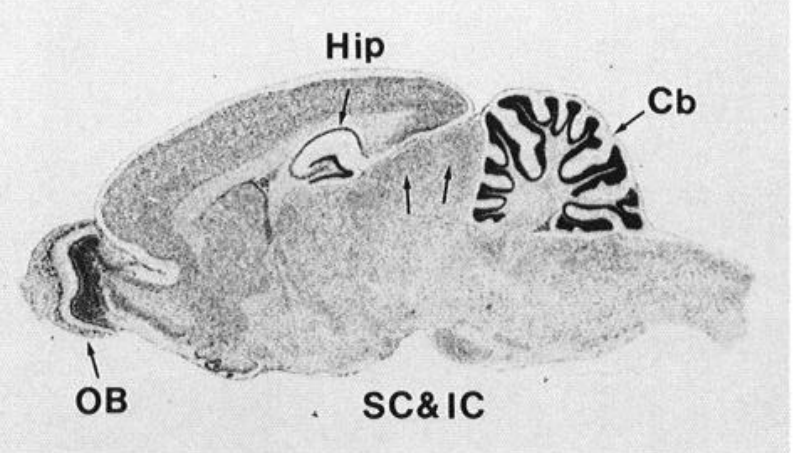

GUANYLYL CYCLASE Antisense

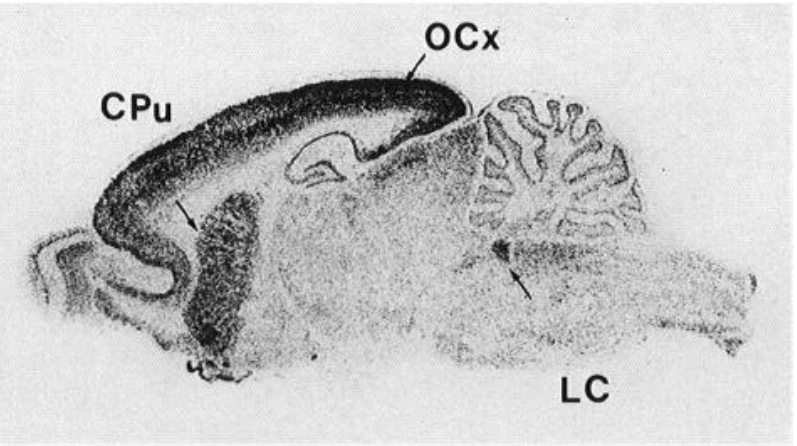

\section{Sense}

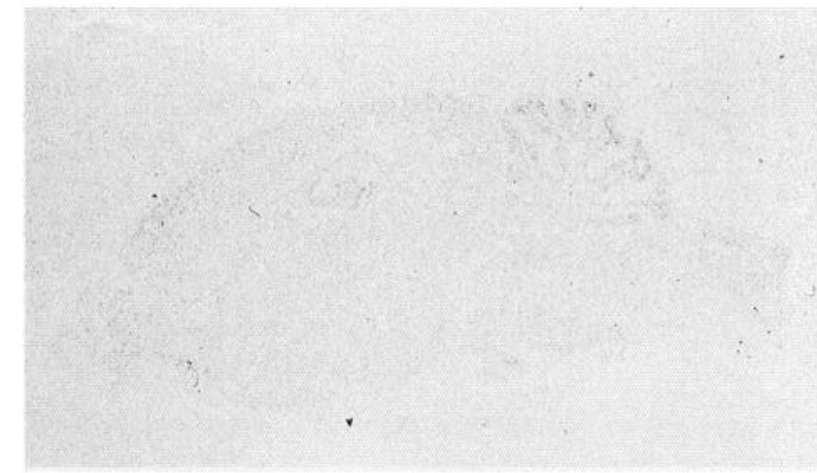

Sense

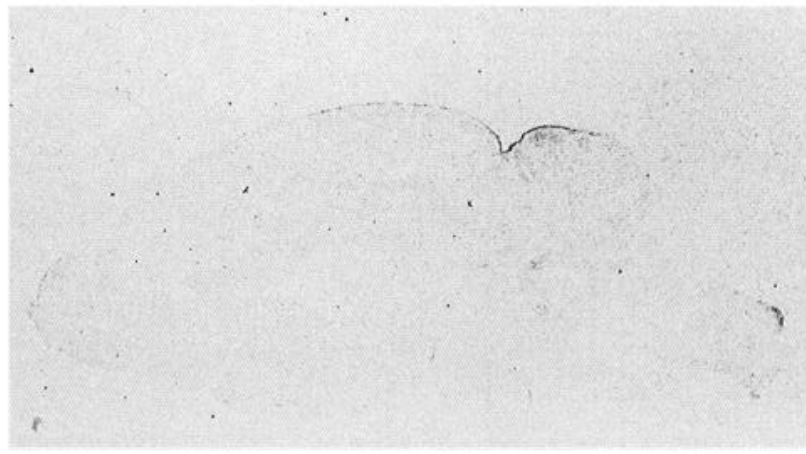

\section{CALMODULIN}

Antisense

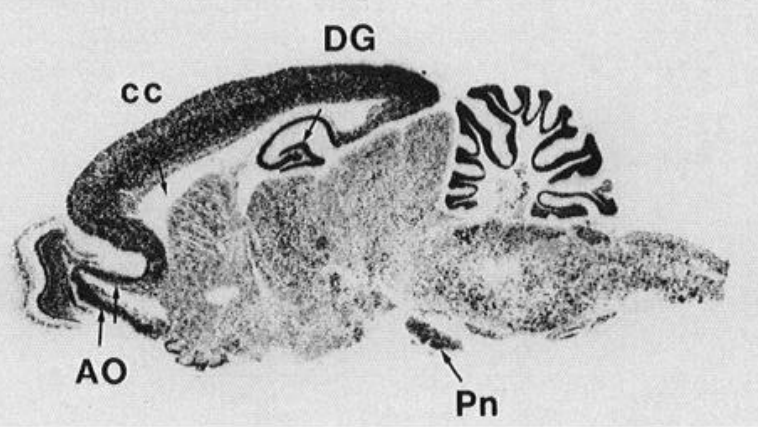

Sense

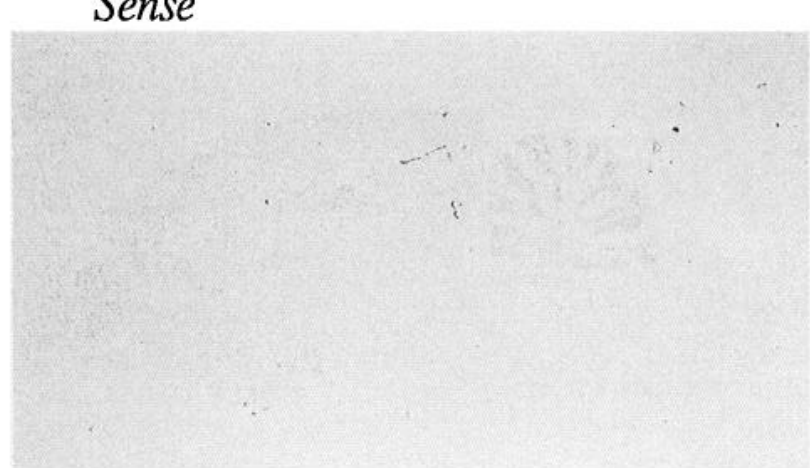

Figure 2. Localization of in situ hybridization signals in the sagittal sections of rat brain with antisense or sense probes of AC, GC, and CaM. $A O$, anterior olfactory nuclei; $C b$, cerebellum; $c c$, corpus callosum; $C P u$, caudate putamen (striatum); $D G$, granule cell layer of the dentate gyrus; $H i p$, hippocampal pyramidal cell layer; $I C$, inferior colliculus; $L C$, locus coeruleus; $O B$, olfactory bulb; $O C x$, occipital cortex; $P n$, pontine nuclei; $S C$, superior colliculus.

were hybridized with ${ }^{35} \mathrm{~S}$-labeled sense RNA probes (Fig. 2), or were prehybridized with a 50-fold excess of nonradioactive antisense RNA probes prior to hybridization (data not shown). Under these conditions, only very faint signals were detected in some brain areas (e.g., the granular layer of the olfactory bulb, the hippocampal formation, and the granule cell layer of the cerebellum). In preliminary experiments, hybrization with ${ }^{35} \mathrm{~S}$ labeled cDNA probes gave the same labeling pattern as that obtained with ${ }^{35} \mathrm{~S}$-labeled antisense RNA probes, and those signals were abolished in RNase A $(100 \mu \mathrm{g} / \mathrm{ml})$-pretreated sections (data not shown). Moreover, differential signals of specific regions in adjacent sections were observed with antisense RNA probes for $\mathrm{AC}, \mathrm{GC}$, and $\mathrm{CaM}$ that were used at the same concentration under the same conditions, indicating that each antisense probe detects its target mRNAs.

In situ hybridization with the AC antisense RNA probe revealed that AC mRNA was widely expressed throughout the brain, although there were regional variations (Figs. 2-5). The AC mRNA signals were abundant in the granule cells and the Purkinje cells of the cerebellum (Figs. 2, 3, 5), in the granule cells of the dentate gyrus (Figs. 2, 3), and in the pyramidal cells of the hippocampus (Figs. 2, 3, 5). Strong signals were also 
ADENYLYL CYCLASE
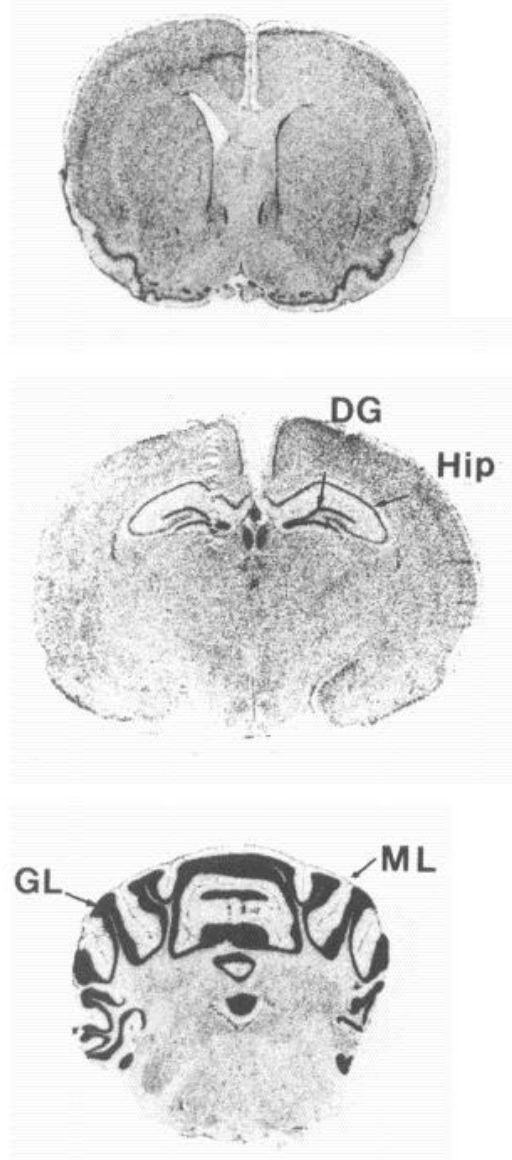

GUANYLYL CYCLASE
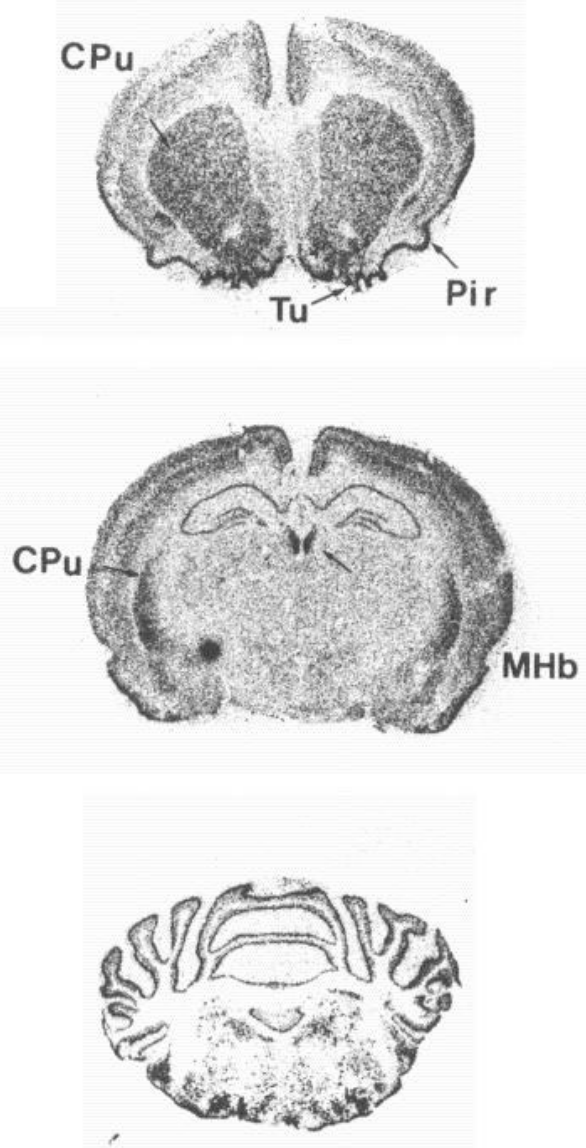

\section{CALMODULIN}
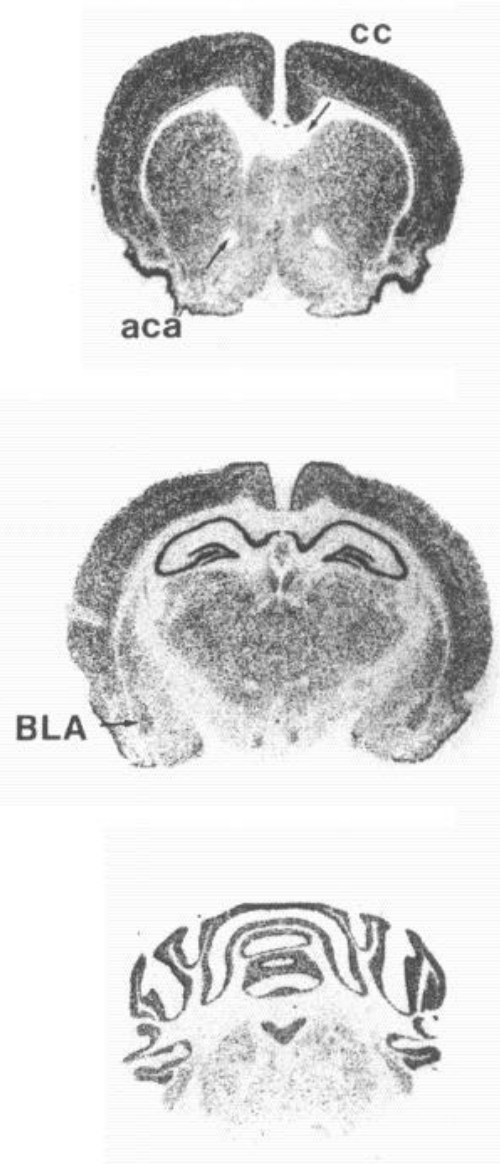

Figure 3. Localization of in situ hybridization signals of AC, GC, and CaM in three coronal sections of the rat brain. aca, anterior commissure, anterior; $B L A$, basolateral amygdaloid nucleus; $c c$, corpus callosum; $C P u$, caudate putamen (striatum); $D G$, dentate gyrus (granule cell layer); $G L$, granule cell layer of the cerebellum; Hip, pyramidal cell layer of the hippocampus; $M H b$, medial habenular nucleus; $M L$, molecular layer of the cerebellum; Pir, piriform cortex; Tu, olfactory tubercle.

observed in the olfactory system in the granular and glomerular layers of the olfactory bulb (Figs. 2, 4), the piriform cortex, and the olfactory tubercle (Fig. 3). The anterior olfactory nuclei were also moderately labeled (Fig. 2). In the cerebral cortex, AC mRNA was expressed moderately and homogeneously in the neuronal cell bodies of each layer (Figs. 2, 3, 5). A moderate amount of labeling was also seen in the subiculum, the inferior and superior colliculus, the striatum, and in the accumbens nuclei (Figs. 2, 3). Although fewer transcripts were present in the thalamus, hypothalamus, and brainstem (Fig. 2), some nuclei located in these regions were moderately labeled (e.g., medial habenular nucleus, anteroventral thalamic nucleus, reticular thalamic nucleus, arcuate nucleus of the hypothalamus, pontine nuclei, and vestibular nuclei). A weak signal was observed over the corpus callosum and anterior commissure (Figs. 2, 3) where glial cells are predominant, indicating that AC mRNA expression occurs in non-neuronal cells. Similarly, significant hybridization signals were obtained in the ependymal lining of ventricle, in the choroid plexus (Figs. 2, 3), and in the pineal gland (Fig. 4).

In contrast to the AC mRNA distribution, GC mRNA was localized in discrete areas of the brain (Figs. 2-5). In the cerebral cortex, GC transcripts were prominent in the pyramidal cells of layers II-III and V, whereas fewer transcripts were present in layers IV and VI (Figs. 2, 3, 5). These signals in the cerebral cortex were more abundant in the occipital cortex (Fig. 2). In addition, many cells in the striatum and the accumbens nuclei were heavily labeled (Figs. 2, 3). Strong signals were also observed in the subiculum (Fig. 2), in the piriform cortex (Fig. 3), in the olfactory tubercle (Fig. 3), in the medial habenular nucleus (Fig. 3), and in the locus coeruleus (Fig. 2). A moderate amount of GC mRNA was observed in the pyramidal cell layer of the hippocampus, in the granule cell layer of the dentate gyrus (Figs. $2,3,5$ ), and in the basolateral amygdaloid nucleus (Fig. 3). In the olfactory bulb, lower amounts of GC mRNA transcripts were observed with a pattern similar to that observed for AC (Figs. 2, 4). In the midbrain, the superior and inferior colliculus were substantially labeled (Fig. 2). In the cerebellum, moderate signal was discretely located in the Purkinje cell layer (Figs. 2, 3,5 ). Only a weak signal was observed in the cerebellar granule cells (Figs. 2, 3, 5), whereas the basket and stellate cells in the molecular layers as well as the Golgi cells in the granule cell layer were moderately labeled by GC probe (data not shown). Significant GC signals were not seen in glial-like cells in the 
ADENYLYL CYCLASE
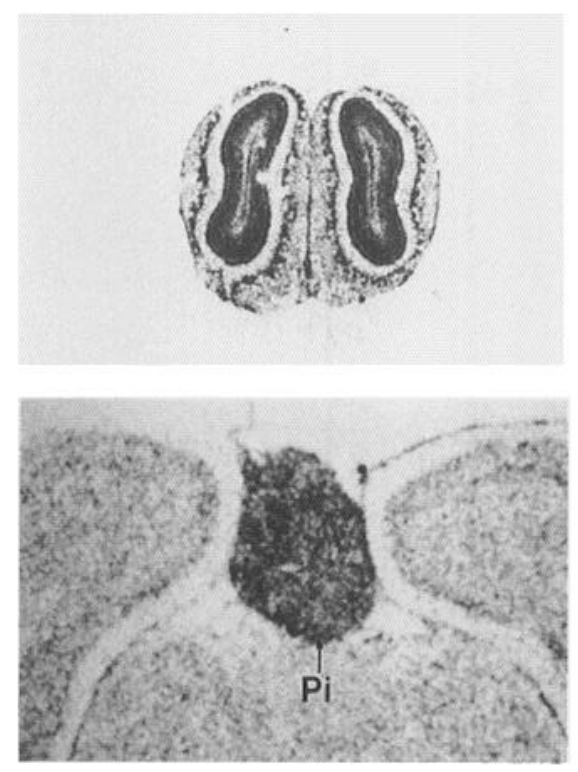

GUANYLYL CYCLASE
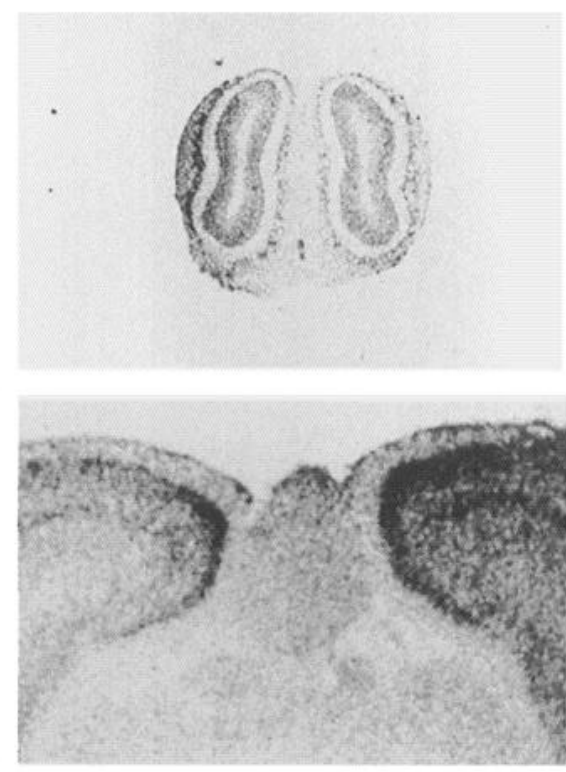

CALMODULIN
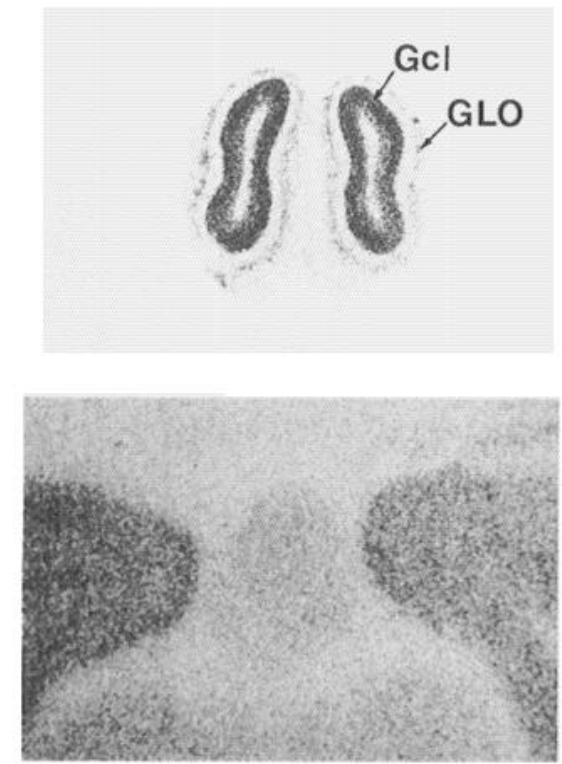

Figure 4. Localization of in situ hybridization signals of AC, GC, and CaM in the olfactory bulb (upper), and pineal gland (lower). Gcl, inner granule cell layer of the olfactory bulb; GLO, glomerular layer of the olfactory bulb; $P i$, pineal gland.

cerebellum. GC mRNA was detected at very low levels in the thalamus, hypothalamus, and lower brainstem, except the pontine nuclei and facial nucleus (Figs. 2, 3).

For most of the brain, the pattern of CaM mRNA distribution overlapped with that of AC and GC mRNAs (Figs. 2-4), but the relative abundance of the signal was markedly different. Marked hybridization signal of $\mathrm{CaM}$ was observed in the cerebral cortex, the anterior olfactory nuclei, the pyramidal cells of hippocampus, and the granule cells of dentate gyrus (Figs. 2, $3,5)$. CaM mRNA was also abundant in the striatum, the accumbens nuclei, and the basolateral amygdaloid nucleus (Fig. 3). In the cerebellum, a marked CaM signal was observed in the Purkinje cells (Fig. 5). The cerebellar granule cells and the deep cerebellar nuclei were also moderately labeled (Figs. 2, 3). CaM mRNA was highly expressed in several nuclei in the thalamus, the hypothalamus, and brainstem (e.g., many thalamic nuclei, pontine nuclei, vestibular nuclei, and reticular nuclei; Figs. 2, 3). A marked difference between CaM mRNA distribution and that of $\mathrm{AC}$ or GC mRNA was seen in non-neuronal cell area, since few CaM transcripts were detected in the corpus callosum, anterior commissure, lateral olfactory tract, and the ventral hippocampal commissure (Figs. 2, 3). The CaM signals in the choroid plexus and pineal gland were also weak (Figs. 24). It was apparent that the CaM mRNA was highly transcribed in neuronal cells.

\section{Discussion}

The present study represents the localizations of $\mathrm{AC}, \mathrm{GC}$, and CaM mRNA expressions in the rat brain by in situ hybridization using antisense RNA probes. Control experiments indicated that most of the observed signals were specific for each target mRNA. First, each antisense RNA probe recognized a specific RNA species by Northern blot of rat brain polyA ${ }^{+}$RNA. Second, only a slight nonspecific hybridization signal was observed in adjacent brain sections with each ${ }^{35} \mathrm{~S}$-labeled sense RNA probe, or in those sections prehybridized with 50 -fold excess nonradioactive antisense RNA probes prior to hybridization. Finally, three different probes, such as AC-, GC-, and CaM-specific probe, gave significant different signals in their intensities and localization, providing the best control for each in situ hybridization data.

Genetic evidence has suggested the presence of several distinct $\mathrm{AC}$ isozymes in the brain. One group is stimulated by $\mathrm{Ca}^{2+}$ CaM (type I, Krupinski et al., 1989; and type III, Bakalyar and Reed, 1990), and another group is insensitive to $\mathrm{Ca}^{2+} / \mathrm{CaM}$ (type II, Feinstein et al., 1991; and type IV, Gao and Gilman, 1991). In the present study, we have used an AC probe prepared from the cDNA encoding human brain AC that was isolated in our laboratory (Parma et al., 1991). Since this cDNA is incomplete, we were unable to express the corresponding protein, and thus to determine its CaM sensitivity. Nevertheless, comparisons of nucleotide sequences have indicated that the cDNA used in this study, which probably codes for a novel mammalian AC (Parma et al., 1991; Stengel et al., in press), has a long cytoplasmic carboxy-terminal similar to type I (Krupinski et al., 1989) and type III (Bakalyar and Reed, 1990) $\mathrm{Ca}^{2+} / \mathrm{CaM}$-sensitive ACs, but not to type II (Feinstein et al., 1991) or type IV (Gao and Gilman, 1991) $\mathrm{Ca}^{2+} / \mathrm{CaM}$-insensitive AC. The in situ hybridization signals of $\mathrm{AC}$ that we obtained in rat brain correlated more closely with the distribution of the $\mathrm{Ca}^{2+} / \mathrm{CaM}$-sensitive $\mathrm{AC}$ as compared to the forskolin-responsive AC. As an example, forskolin exerted the strongest stimulatory effect on AC activity in the striatum, whereas a weaker in situ hybridization signal was detected in this region as compared to other regions such as the cerebellum and hippocampus. In contrast, the effects of $\mathrm{Ca}^{2+} /$ $\mathrm{CaM}$ were more pronounced on the $\mathrm{AC}$ from the cerebellum and hippocampus than that from the striatum, in good correlation with the in situ hybridization data. It is therefore likely that the hybridization signals observed in our study correspond to the distribution of mRNA for a $\mathrm{Ca}^{2+} / \mathrm{CaM}$-sensitive $\mathrm{AC}$. The present results exhibit an overlap of mRNA distribution for $\mathrm{AC}$ 

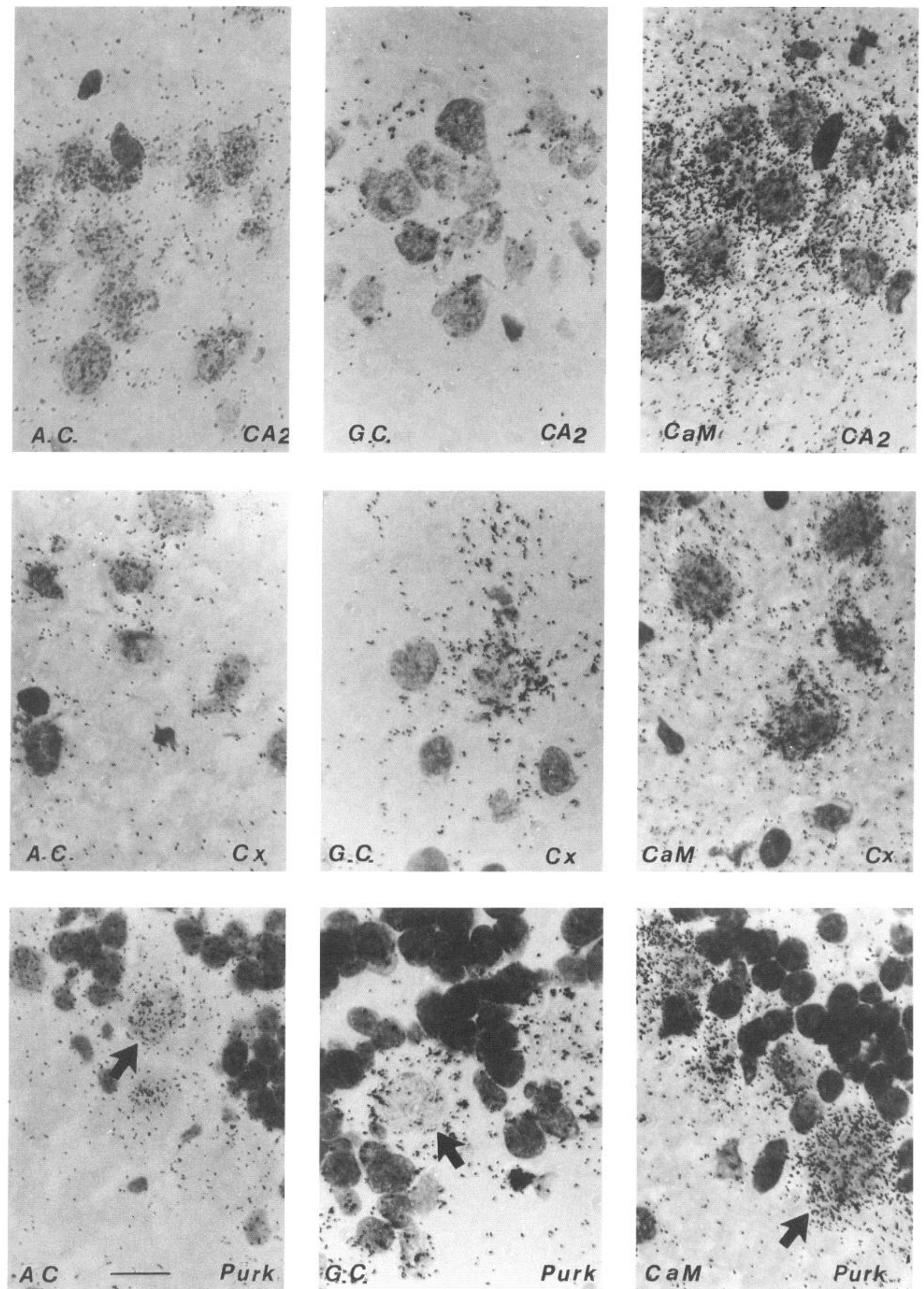

Figure 5. Cellular distribution of in situ hybridization signals of AC (left), GC (middle), and CaM (right) in the hippocampal CA2 pyramidal cells (upper), the cerebral cortex layer V (middle), and the granule and Purkinje cell layers of the cerebellum (lower). Arrows in the lower panels indicate the Purkinje cells in the cerebellum. Exposure for emulsion-coated slide was 1 month. Scale bar, $10 \mu \mathrm{m}$. 
and $\mathrm{CaM}$ in neuronal cells in the brain. In contrast, there was a difference in the hybridization signal between $\mathrm{AC}$ and $\mathrm{CaM}$ in the areas containing predominantly glial cells. Since the glial cells have been shown to possess $\mathrm{Ca}^{2+} / \mathrm{CaM}$-sensitive $\mathrm{AC}$ (Bockaert, 1981), it is possible that the amount of CaM message present in glial cells may be below the level of detection by in situ hybridization. This may be relevant to the requirement of large amounts of CaM for the neuronal cell functions (Liu and Storm, 1990).

The localization of AC mRNA in the brain detected by in situ hybridization is largely different from the results of autoradiographic binding studies using a radiolabeled forskolin to localize the AC enzyme (Worley et al., 1986; Poat et al., 1988). A substantial difference between AC mRNA signals and forskolin binding sites is seen in the striatum and substantia nigra, where forskolin binding sites were densely localized but AC mRNA was only slightly expressed. As we observed the highest $\mathrm{AC}$ activity in response to forskolin in the striatum, the difference between the localization of forskolin binding sites and that of the present in situ hybridization signal may be due to the nonselective binding of forskolin to all $\mathrm{AC}$ forms, whereas the in situ hybridization visualized a specific $\mathrm{AC}$, probably a $\mathrm{Ca}^{2+}$ CaM-sensitive one, as mentioned above. In addition, even in the regions where the in situ hybridization signal and forskolin binding are colocalized, the forskolin binding seems to visualize dendritic or axonal projection areas rather than neuronal cell bodies. In the cerebellum, for example, we demonstrated AC mRNA in the granule and Purkinje cells, whereas a significant forskolin binding was found in the molecular layer (Worley et al., 1986), which contains the axons and terminals of granule cclls and the large dendrites of Purkinje cells. These results indicate that $\mathrm{AC}$ of the cerebellar granule cells predominantly exists in the presynaptic terminals, whereas that of the Purkinje cells is localized at postsynaptic elements. A similar translocation mechanism of AC enzyme can account for the significant labeling by forskolin of the dendrites and the mossy fibers of the granule cells of the dentate gyrus (Worley et al., 1986). It should also be mentioned that forskolin interacts not only with $\mathrm{AC}$, but also with some other proteins, such as glucose transporters, nicotinic $\mathrm{ACh}$ receptors, and voltage-dependent $\mathrm{K}^{+}$ channels (Laurenza et al., 1989).

Since AC mRNA is widely distributed in the neuronal cells in the brain, these localization patterns do not match with those of any one neurotransmitter system. Interestingly, the distribution of AC mRNA is very similar to that of mRNAs for $G_{s}$ and $G_{i_{2}}$ (Brann et al., 1987). This reflects that multiple neurotransmittcrs can affect $\mathrm{Ca}^{2+} / \mathrm{CaM}$-sensitive $\mathrm{AC}$, since this enzyme is known to be regulated not only by a change in intracellular $\mathrm{Ca}^{2+}$ concentration but also by $\mathrm{G}$-proteins (Harrison et al., 1989). It has been suggested that the basal level of cAMP in the brain is maintained by $\mathrm{Ca}^{2+} / \mathrm{CaM}$ - rather than $\mathrm{G}$-proteindependent mechanisms (Brostrom et al., 1975; Salter et al., 1981; Cooper et al., 1988), and that the stimulation of $\mathrm{Ca}^{2+}$ CaM-sensitive $\mathrm{AC}$ is required for demonstrating the inhibitory effects of various neurotransmitters on brain AC (Ahlijanian and Cooper, 1987; Perez-Reyes and Cooper, 1987). Taken together, $\mathrm{Ca}^{2+} / \mathrm{CaM}$-sensitive $\mathrm{AC}$ is likely involved in processes that are common to several neuronal populations such as regulation of neurotransmitter synthesis and of polarity of neuroplasmic membrane by modulating ion channel activities (Nestler and Greengard, 1983; Nairn et al., 1985). The high localization of AC mRNA in the neuronal cells of the cerebellum and hippocampus also suggests a possible role for this enzyme in the long-term changes in synaptic transmission (Voronin, 1983; Ito, 1989). In addition, the results that show the positive AC mRNA signal in the ependymal lining of the ventricle, the choroid plexus, and the pineal gland indicate an involvement of $\mathrm{Ca}^{2+} / \mathrm{CaM}$-sensitive $\mathrm{AC}$ in the functional regulation of thesc tissues.

Recently, Xia et al. (1991) have shown the AC mRNA localization in the rat brain by in situ hybridization using RNA probes derived from the sequence of bovine brain type $\mathrm{I}, \mathrm{Ca}^{2+}$ CaM-sensitive AC cDNA. In most brain regions, but not all, the present results are in agreement with their study, which has shown a strong signal in the hippocampus, the granule cell layer of the cerebellum, and the olfactory system. However, they did not obtain a positive signal of AC mRNA in the striatum, the thalamus, the hypothalamus, and the brainstem, where we identified both an $\mathrm{AC}$ message and a $\mathrm{Ca}^{2+} / \mathrm{CaM}$-sensitive $\mathrm{AC}$ activity. Biochemical studies have also shown the presence of $\mathrm{Ca}^{2+} / \mathrm{CaM}-$ sensitive $\mathrm{AC}$ activity in the striatum (Ahlijanian et al., 1987; Mollner and Pfeuffer, 1988). The discrepancy between the study of Xia et al. (1991) and our own might be due to the different probes used for in situ hybridization analysis. It is also possible that our results show the distribution of an additional $\mathrm{Ca}^{2+} / \mathrm{CaM}$-sensitive AC other than type I AC. Since both studies are based on $\mathrm{AC}$ cDNA from different species as probes, further investigations using rat specific probes are necessary to address this question.

The present study is the first to demonstrate the distribution and cellular localization of GC mRNA in the CNS. Until now, the GC distributions in the brain have been shown by immunohistochemistry using either cGMP antibodies (Chan-Palay and Palay, 1979) or soluble GC antibodies (Ariano et al., 1982; Nakane et al., 1983). The localization of GC mRNA in the brain, by in situ hybridization, provides more direct information about the neuronal populations that synthesize soluble GC. In general, our results fit well with the detection by immunostaining of soluble GC.

In the cerebral cortex, high levels of GC mRNA are expressed in the pyramidal cells of layers II-III and V, indicating that the GC. system takes part in the signal transduction of selective neurons organizing specific functions of the cerebral cortex. These results, along with a recent work of Wilcox et al. (1991) done on primates, argue for the soluble GC as the main type of CGMPgenerating enzyme in these two layers of the cerebral cortex. As a matter of fact, these authors revealed the absence of hybridization, in this region of the brain, of probes specific for atrial natriuretic factor receptors $A$ and $B$, which represent membrane forms of $\mathrm{GC}$. This statement should be confirmed in rodent brain.

The soluble GC mRNA is also abundant in many cell types of the striatum, where it has been shown that cGMP levels are markedly increased by neurotransmitters such as ACh (Hanley and Iversen, 1978). In the present study, we demonstrated the highest nitroprusside-responsive GC activity in the striatum as compared to other brain regions so far tested. This observation is in agreement with the measurements done by Hofmann et al. (1977), who found a high cytosolic GC activity in the rat striatum. This region of the brain is known to contain many local circuits involving cholinergic neurons, and to receive a number of projections from the cerebral cortex by glutamate-containing neurons (Brown, 1991).

In the cerebellum, due to the highly ordered arrangement of 
cells, with relatively few cell types, more numerous analyses have been done, as compared to other brain regions, with respect to the GC system. In the present study, we found that GC mRNA is highly expressed in the Purkinje cells. This is consistent with the immunohistochemical localization of soluble GC (Ariano et al., 1982; Nakane et al., 1983) and cGMP-dependent protein kinase (Lohmann et al., 1981) in the Purkinje cells. These results arc relcvant to the previous finding that stimulation of the climbing fibers, which provide a monosynaptic input to the Purkinje cells, strikingly increases cerebellar cGMP levels (Biggio and Guidotti, 1976; Oltmans et al., 1987). All these observations, however, are at variance with the absence of cGMP immunostaining in the Purkinje cells (De Vente et al., 1990). The measurement of cGMP reflects the conjunction of synthesis and degradation of this compound, and even in the presence of phosphodiesterase inhibitor such as 3-isobutyl-1-methylxanthine, it is difficult to prevent substantial degradation of cGMP (De Vente et al., 1990). As a matter of fact, it has already been observed that a good negative correlation exists between regional phosphodiesterase activity and cGMP levels (Greenberg et al., 1978). Apart from Purkinje cells, we observed signals on the basket and stellate cells located in the molecular layer in accordance with previous results obtained with antibodies (Ariano et al., 1982) but we could not find a strong GC mRNA signal in glial cells. This is at variance with the GC localization observed in the astrocytes using antibodies specific for the soluble GC (Nakane et al., 1983) or cGMP (De Vente et al., 1990), although immunoreactions for this GC system are still giving conflicting results in this type of cell (Ariano et al., 1982).

The distinct distribution, in the CNS, of $m$ RNAs for $\mathrm{GC}$ and AC suggests a differential role for each cyclic nucleotide in neurotransmission. As pointed out by Nakane et al. (1983), the immunohistochemical distribution of GC seems intimately correlated with muscarinic cholinergic neurotransmission, and there is now accumulating evidence that cGMP mediates glutamate receptor-induced effects (Garthwaite et al., 1988). Recently, the distributions of both NMDA and non-NMDA subtypes of glutamate receptors in the brain have been characterized by binding of specific ligands (Young and Fagg, 1990) and by in situ hybridization (Moriyoshi et al., 1991; Pellegrini-Giampietro et al., 1991). The GC mRNA localization extensively overlapped with these glutamate receptor localizations. The present results demonstrate that GC mRNA is highly expressed in the occipital cortex, where glutamate receptors play an important role for the detection of the visual signal accompanied with long-term potentiation of synaptic transmission (Artola and Singer, 1987; Cline et al., 1987). These results support the concept that cGMP is involved in glutamate receptor-mediated neurotransmission and the long-term change in the synaptic transmission (Shibuki and Okada, 1991).

It has been established that stimulation of glutamate receptor gates $\mathrm{Ca}^{2+}$ channel, leading to $\mathrm{Ca}^{2+}$ influx from the extracellular space, thereby activating the NO synthase in a CaM-dependent manner (Bredt et al., 1990). This enzyme generates NO from arginine, NO being a potent activator of the soluble form of GC. Recently, this enzyme has been identified (Bredt and Snyder, 1990) and localized in the CNS either by immunohistochemistry (Bredt et al., 1990) or by in situ hybridization (Bredt et al., 1991). The localization of soluble GC mRNA largely overlapped with the signal detected for NO synthase, an observation compatible with the direct interaction of NO with soluble GC. Nevertheless, this overlap is not complete. In the cerebel- lum, for instance, NO synthase is absent from the Purkinje cells, but its mRNA was heavily expressed in the granule and basket cells. However, this seems to be rather consistent with models for NO action in the nervous system, in which activated cells release NO to stimulate soluble GC in the neighboring cells (Garthwaite, 1991). A substantial difference between GC and NO synthase mRNA localization is seen in the striatum, where only a few cclls cxpress the NO synthase signal, whereas we observed a strong response for GC $\mathrm{mRNA}$ throughout this area. The freely diffusible nature of NO is not sufficient to postulate for an important migration of this compound, due to its short half-life. It is probable that other GC stimulators, such as unsaturated fatty acid peroxide derived from the arachidonic acid cascade, are involved in the regulation of GC activity (Goldberg et al., 1978). One also cannot exclude different subtypes of NO synthase in the brain.

The present study is also the first to demonstrate the CaM mRNA distribution in the CNS. The results expand previous studies that showed the distribution of CaM activity in rat brain (Zhou et al., 1985). CaM mRNA signals largely overlapped with the mRNA signals for AC as well as GC. This is in accordance with the regulatory role of $\mathrm{CaM}$ in $\mathrm{AC}$ activity as well as $\mathrm{GC}$ activity indirectly via NO synthase. Our overall results are consistent with the fact that $\mathrm{CaM}$ mediates $\mathrm{Ca}^{2}+$ regulation of a number of enzymes that play significant neuromodulatory roles. For example, CaM-dependent protein kinase II has been shown to play an essential role for allowing the synaptic vesicle to undergo exocytosis (Llinàs et al., 1985). CaM has also been suggested to be involved in axon elongation and in synaptic organization (Hooper and Kelly, 1984; Koenig et al., 1985). Interestingly, CaM mRNA is highly expressed in the cerebral cortex, the pyramidal cells of hippocampus, the granule cells of dentate gyrus, and the Purkinje cells of the cerebellum, where the neuronal functions are known to be modulated by synaptic plasticity (Voronin, 1983; Ito and Karachot, 1989). It has been suggested that in neuronal cells, a large amount of $\mathrm{CaM}$ is present as a complex with neuromodulin (GAP-43/B-50), a neurospecific CaM binding protein (Liu and Storm, 1989). Neuromodulin is known to exist at high levels in developing neurons, and to play a role in the development and the functional modulation of synaptic relationships. Although neuromodulin levels decline after the establishment of mature synaptic relationships, a considerable amount of this protein still persists in the adult brain (Benowitz et al., 1988). In the forebrain, the distribution of CaM mRNA is similar to that of neuromodulin as demonstrated by immunohistochemistry (Benowitz et al., 1988). An important biochemical role of neuromodulin is the regulation of free $\mathrm{CaM}$ concentrations in neuronal cells, since phosphorylation of neuromodulin by protein kinase $\mathrm{C}$ leads to release of $\mathrm{CaM}$ in activated neuronal cells (Liu and Storm, 1989). It is possible that phospholipase $\mathrm{C}$-coupled receptor stimulations in neuronal cells initiate cyclic nucleotide second messenger systems indirectly through protein kinase $\mathrm{C}$-mediated increase in available CaM as well as inositol-1,4,5-trisphosphate-induced elevation of cytoplasmic free $\mathrm{Ca}^{2+}$.

In conclusion, using in situ hybridization histochemistry, we have visualized the distribution and cellular localization of $\mathrm{mRNA}$ for $\mathrm{AC}, \mathrm{GC}$, and $\mathrm{CaM}$ in rat brain. The differential distributions of these mRNAs suggest their specific role in synaptic transmission and neuronal function. Further investigation of cellular expression of these mRNAs under different conditions would provide additional information about the signifi- 
cancc of the cyclic nucleotide second messenger system and $\mathrm{CaM}$ in physiological and pathological function in the CNS.

\section{References}

Ahlijanian MK, Cooper DMF (1987) Calmodulin may play a pivotal role in neurotransmitter-mediated inhibition and stimulation of rat cerebellar adenylate cyclase. Mol Pharmacol 32:127-132.

Ahlijanian MK, Halford MK, Cooper DMF (1987) $\mathrm{Ca}^{2+} /$ calmodulin distinguishes between guanyl-5'-yl-imidodiphosphate- and opiatemediated inhibition of rat striatal adenylate cyclase. J Neurochem 49:1308-1315.

Ariano MA, Lewicki JA, Brandwein HJ, Murad F (1982) Immunohistochemical localization of guanylate cyclase within neurons of rat brain. Proc Natl Acad Sci USA 79:1316-1320.

Artola A, Singer W (1987) Long-term potentiation and NMDA receptors in rat visual cortex. Nature 330:649-652.

Augustine GJ, Charlton MP, Smith SJ (1987) Calcium action in synaptic transmission. Annu Rev Neurosci 10:633-639.

Bakalyar HA, Reed RR (1990) Identitication of a specialized adenylyl cyclase that may mediate odorant detection. Science 250:1403-1406.

Benowitz LI, Apostolides PJ, Perrone-Bizzozero N, Finklestein SP, Zwiers $\mathrm{H}$ (1988) Anatomical distribution of the growth-associated protein GAP-43/B-50 in the adult rat brain. J Neurosci 8:339-352.

Berridge MJ (1988) Inositol lipids and calcium signalling. Proc R Soc Lond [Biol] 234:359-387.

Biggio G, Guidotti A (1976) Climbing fiber activation and $3^{\prime}, 5^{\prime}$-cyclic guanosine monophosphatc (cGMP) content in cortex and deep nuclei of cerebellum. Brain Res 107:365-373.

Bockaert J (1981) General characteristics, localization, and adaptative responsiveness of neurotransmitter-sensitive adenylate cyclases in the central nervous system. Adv Cyclic Nucleotide Res 14:611-628.

Brann MR, Collins RM, Spiegel A (1987) Localization of mRNAs encoding the $\alpha$-subunits of signal-transducing G-proteins within rat brain and among peripheral tissues. FEBS Lett 222:191-198.

Bredt DS. Snyder SH (1990) Isolation of nitric oxide synthetase, a calmodulin-requiring enzyme. Proc Natl Acad Sci USA 87:682-685.

Bredt DS, Hwang PM, Snyder SH (1990) Localization of nitric oxide synthase indicating a neural role for nitric oxide. Nature 347:768770.

Bredt DS, Hwang PM, Glatt CE, Lowenstein C, Reed RR, Snyder SH (1991) Cloned and expressed nitric oxide synthase structurally resembles cytochrome P-450 reductase. Nature 351:714-718.

Brostrom CO, Huang Y-C, Breckenridge BM, Wolff DJ (1975) Identification of a calcium-binding protein as a calcium-dependent regulator of brain adenylate cyclase. Proc Natl Acad Sci USA 72:64-68.

Brown AG (1991) Nerve cells and nervous systems, an introduction to neuroscience. London: Springer.

Chan-Palay V, Palay SL (1979) Immunocytochemical localization of cyclic GMP: light and electron microscope evidence for involvement of neuroglia. Proc Natl Acad Sci USA 76:1485-1488.

Cheung WY, Bradham LE, Lynch TJ, Lin YM, Tallant EA (1975) Protein activator of cyclic $3^{\prime}: 5^{\prime}$-nucleotide phosphodiesterase of bovine or rat brain also activates its adenylate cyclase. Biochem Biophys Res Commun 66:1055-1062.

Cline HT, Debski EA, Constantine-Paton M (1987) $N$-mcthyl-D-aspartate receptor antagonist desegregates eye-specific stripes. Proc Natl Acad Sci USA 84:4342-4345.

Cooper DMF, Ahlijanian MK, Perez-Reyes E (1988) Calmodulin plays a dominant role in determining neurotransmitter regulation of neuronal adenylate cyclase. J Cell Biochem 36:417-427.

De Vente J, Bol JGJM, Berkelmans HS, Schipper J, Steinbusch HMW (1990) Immunocytochemistry of cGMP in the cerebellum of the immature, adult, and aged rat: the involvement of nitric oxide. A micropharmacological study. Eur J Neurosci 2:845-862.

Feinstein PG, Schrader KA, Bakalyar HA, Tang W-J, Krupinski J, Gilman AG, Reed RR (1991) Molecular cloning and characterization of $\mathrm{Ca}^{2+} /$ calmodulin-insensitive adenylyl cyclase from rat brain. Proc Natl Acad Sci USA 88:10173-10177.

Gao B, Gilman AG (1991) Cloning and expression of a widely distributed (type IV) adenylyl cyclase. Proc Natl Acad Sci USA 88: 10178-10182.

Garthwaite J (1991) Glutamate, nitric oxide and cell-cell signalling in the nervous system. Trends Neurosci 14:60-67.

Garthwaite J, Charles SL, Chess-Williams R (1988) Endothelium- derived relaxing factor release on activation of NMDA receptors suggests role as intercellular messenger in the brain. Nature 336:385388.

Gilman AG (1987) G proteins: transducers of reccptor-gencrated signals. Annu Rev Biochem 56:615-649.

Goldberg ND, Graff G, Haddox MK, Stephenson JH, Glass DB, Moser ME (1978) Redox modulation of splenic cell soluble guanylate cyclase activity: activation by hydrophilic and hydrophobic oxidants represented by ascorbic and dehydroascorbic acid, fatty acid hydroperoxides, and prostaglandin endoperoxides. Adv Cyclic Nucleotide Res 9:101-130.

Greenberg LH, Troyer E, Ferrendelli JA, Weiss B (1978) Enzymatic regulation of the concentration of cyclic GMP in mouse brain. Neuropharmacology 17:737-745.

Haguenauer-Tsapis R, Salah AB, Lacombe M-L, Hanoune J (1981) Trypsin solubilization of rat liver membrane-bound guanylate cyclase results in a form kinetically distinct from the cytosolic enzyme. J Biol Chem 256:1651-1655.

Hanley MR, Iversen LL (1978) Muscarinic cholinergic receptors in rat corpus striatum and regulation of guanosine cyclic 3',5'-monophosphate. Mol Pharmacol 14:246-265.

Harrison JK, Hewlett GHK, Gnegy ME (1989) Regulation of calmodulin-sensitive adenylate cyclase by the stimulatory G-protein, Gs. J Biol Chem 264:15880-15885.

Harrison PJ, Pearson RCA (1990) In situ hybridization histochemistry and the study of gene expression in the human brain. Prog Neurobio 34:271-312.

Hofmann M, Spano PF, Trabucchi M, Kumakura K (1977) Guanylate cyclase activity in various rat brain areas. J Neurochem 29:395-396.

Hooper JE, Kelly RB (1984) Calmodulin is tightly associated with synaptic vesicles independent of calcium. J Biol Chem 259:148-153.

Ito M (1989) Long-term depression. Anmu Rev Neurosci 12:85-102.

Ito M, Karachot L (1989) Long-term desensitization of quisqualatespecific glutamate receptors in Purkinje cells investigated with wedge recording from rat cerebellar slices. Neurosci Res 7:168-171.

Kebabian JW (1977) Biochemical regulation and physiological significance of cyclic nucleotides in the nervous system. Adv Cyclic Nucleotide Res 8:421-508.

Koenig E, Kinsman S, Repasky E, Sultz L (1985) Rapid mobility of motile varicosities and inclusions containing $\alpha$-spectrin, actin, and calmodulin in regenerating axons in vitro. J Neurosci 5:715-729.

Krupinski J, Coussen F, Bakalyar HA, Tang W-J, Feinstein PG, Orth K, Slaughter C, Reed RR, Gilman AG (1989) Adenylyl cyclase amino acid sequence: possible channel- or transporter-like structure. Science 244:1558-1564.

Laurenza A, Sutkowski EM, Seamon KB (1989) Forskolin: a specific stimulator of adenylyl cyclase or a diterpene with multiple sites of action? Trends Pharmacol Sci 10:442-447.

Liu Y, Storm DR (1989) Dephosphorylation of neuromodulin by calcineurin. J Biol Chem 264:12800-12804.

Liu Y, Storm DR (1990) Regulation of free calmodulin levels by neuromodulin: neuron growth and regeneration. Trends Pharmacol Sci 11:107-111.

Llinàs R, McGuinness TL, Leonard CS, Sugimori $M$, Greengard $P$ (1985) Intraterminal injection of synapsin I or calcium/calmodulindependent protein kinase II alters neurotransmitter release at the squid giant synapse. Proc Natl Acad Sci USA 82:3035-3039.

Lohmann SM, Walter U, Miller PE, Greengard P, De Camilli P (1981) Immunohistochemical localization of cyclic GMP-dependent protein kinase in mammalian brain. Proc Natl Acad Sci USA 78:653-657.

Mollner S, Pfeuffer T (1988) Two different adenylyl cyclases in brain distinguished by monoclonal antibodies. Eur J Biochem 171:265271.

Moriyoshi K, Masu M, Ishii T, Shigemoto R, Mizuno M, Nakanishi S (1991) Molecular cloning and characterization of the rat NMDA receptor. Nature 354:31-37.

Murad F, Mittal CK, Arnord WP, Katsuki S, Kimura H (1978) Guanylate cyclase: activation by azide, nitro compounds, nitric oxide, and hydroxyl radical and inhibition by hemoglobin and myoglobin. Adv Cyclic Nucleotide Res 9:145-158.

Nairn AC, Ilemmings HC Jr, Grecngard P (1985) Protein kinases in the brain. Annu Rev Biochem 54:931-976.

Nakane M, Ichikawa M, Deguchi T (1983) Light and electron microscopic demonstration of guanylate cyclase in rat brain. Brain Res 273: 9-15.

Nakane M, Saheki S, Kuno T, Ishii K, Murad F (1988) Molecular 
cloning of a cDNA coding for 70 kilodalton subunit of soluble guanylate cyclase from rat lung. Biochem Biophys Res Commun 157:11391147.

Nakane M, Arai K, Saheki S, Kuno T, Buechler W, Murad F (1990) Molecular cloning and expression of cDNAs coding for soluble guanylate cyclase from rat lung. J Biol Chem 265:16841-16845.

Nestler EJ, Greengard P (1983) Protein phosphorylation in the brain. Nature 305:583-588.

Oltmans GA, Moss LE, Lorden JF, Beales M (1987) Acute and chronic effects of climbing fiber lesion on cerebellar cyclic guanosine monophosphate. Brain Res 437:183-188.

Panchenko MP, Tkachuk VA (1984) Calmodulin activates adenylate cyclase from rabbit heart plasma membranes. FEBS Lett 174:50-53.

Parma J, Stengel D, Gannage MH, Poyard M, Barouki R, Hanoune J (1991) Sequence of a human brain adenylyl cyclase partial cDNA: evidence for a consensus cyclase specific domain. Biochem Biophys Res Commun 179:455-462.

Pellegrini-Giampietro DE, Bennett MVL, Zukin RS (1991) Differential expression of three glutamate receptor genes in developing rat brain: an in situ hybridization study. Proc Natl Acad Sci USA 88: 4157-4161.

Perez-Reyes E, Cooper DMF (1987) Calmodulin stimulation of the rat cerebral cortical adenylate cyclase is required for the detection of guanine nucleotide- or hormone-mediated inhibition. Mol Pharmacol 32:212-216

Piascik MT, Babich M, Rush ME (1983) Calmodulin stimulation and calcium requirement of smooth muscle adenylate cyclase activity. J Biol Chem 259:10913-10918.

Poat JA, Cripps HE, Iversen LL (1988) Differences between highaffinity forskolin binding sites in dopamine-rich and other regions of rat brain. Proc Natl Acad Sci USA 85:3216-3220.

Putkey JA, Ts'ui KF, Tanaka T, Lagacé L, Stein JP, Lai EC, Means AR (1983) Chicken calmodulin genes. A species comparison of cDNA sequences and isolation of a genomic clone. J Biol Chem 258:1186411870.

Rosenberg GB, Storm DR (1987) Immunological distinction between calmodulin-sensitive and calmodulin-insensitive adenylate cyclases. J Biol Chem 262:7623-7628.

Salter RS, Krinks MH, Klee CB, Neer EJ (1981) Calmodulin activates the isolated catalytic unit of brain adenylate cyclase. $J$ Biol Chem 256:9830-9833.
Schulz S, Yuen PST, Garbers DL (1991) The expanding family of guanylyl cyclases. Trends Pharmacol Sci 12:116-120.

SenGupta B, Friedberg F, Detera-Wadleigh SD (1987) Molecular analysis of human and rat calmodulin complementary DNA clones. Evidence for additional active genes in these species. J Biol Chem 262: $16663-16670$.

Shibuki K, Okada D (1991) Endogenous nitric oxide release required for long-term synaptic depression in the cerebellum. Nature 349:326328.

Stengel D, Hanoune J (1981) The catalytic unit of ram sperm adenylate cyclase can be activated through the guanine nucleotide regulatory component and prostaglandin receptors of human erythrocyte. J Biol Chem 256:5394-5398.

Stengel D, Parma J, Gannagé M-H, Roeckel N, Mattei M-G, Barouki R, Hanoune J (1992) Different chromosomal localization of two adenylyl cyclase genes expressed in human brain. Hum Genet, in press.

Sutherland EW, Rall TW, Menon T (1962) Adenyl cyclase: I. Distribution, preparation, and properties. J Biol Chem 237:1220-1227.

Valverde I, Vandermeers A, Anjaneyala R, Malaisse WJ (1979) Calmodulin activation of adenylate cyclase of pancreatic islets. Science 206:225-227.

Voronin LL (1983) Long-term potentiation in the hippocampus. Neuroscience 10:1051-1069.

Wilcox JN, Augustine A, Goeddel DV, Lowe DG (1991) Differential regional expression of three natriuretic peptide receptor genes within primate tissues. Mol Cell Biol 11:3454-3462.

Worley PF, Baraban JM, Souza EBD, Snyder SH (1986) Mapping second messenger systems in the brain: differential localizations of adenylate cyclase and protein kinase C. Proc Natl Acad Sci USA 83: 4053-4057.

Xia Z, Refsdal CD, Merchant KM, Dorsa DM, Storm DR (1991) Distribution of mRNA for the calmodulin-sensitive adenylyl cyclase in rat brain: expression in areas associated with learning and memory. Neuron 6:431-443.

Young AB, Fagg GE (1990) Excitatory amino acid receptors in the brain: membrane binding and receptor autoradiographic approaches. Trends Pharmacol Sci 1 1:126-133.

Zhou L-W, Moyer JA, Muth EA, Clark B, Palkovits M, Weiss B (1985) Regional distribution of calmodulin activity in rat brain. J Neurochem 44:1657-1662. 